\title{
GESTÃO DE COMPRAS NO SERVIÇO PÚBLICO: UM ESTUDO DE CASO EM UMA UNIVERSIDADE FEDERAL POTIGUAR
}

\author{
R. N. O. NASCIMENTO ${ }^{1}$ e L. G. SANTOS \\ Instituto Federal de Educação, Ciência e Tecnologia do Rio Grande do Norte \\ rayanna.oliveira88@gmail.com eluciana.santos@ifrn.edu.br
}

Artigo submetido em 26/07/2018 e aceito em 01/08/2018

DOI: 10.15628/empiricabr.2018.7552

\section{RESUMO}

O estudo objetivou identificar quais práticas de compras são adotadas nas Instituições Federais de Ensino Superior do Alto Oeste Potiguar, a fim de investigar o nível de eficiência da gestão dos aspectos procedimentais. Para tanto, utilizou-se o estudo de caso que se pauta na aplicação de questionários com perguntas abertas e fechadas, na análise de conteúdo e na observação direta. Os questionários foram aplicados junto aos servidores que atuam como gestores de compras e também aos servidores solicitantes. A apreciação dos questionários foi pautada na tabulação dos dados obtidos e cruzados com as informações levantadas a partir da análise da estrutura administrativa. Considerando os achados, constatou-se que, apesar de as rotinas praticadas pela UFERSA Campus Pau dos Ferros se colocarem de maneira coerente, em diferentes estágios do processo de compras existem falhas em aspectos importantes inerentes à eficiência. Essas lacunas podem gerar consequências relacionadas com a inobservância de dispositivos legais, o aumento dos gastos, as compras desnecessárias, a falta de materiais no momento em que se precisa. Sendo necessário que os gestores implementem políticas para sanar essas lacunas e, consequentemente, propiciar maior precisão no manejo dos recursos públicos direcionados a essa instituição.

PALAVRAS-CHAVE: Gestão de compras, compras públicas, eficiência organizacional.

\section{MANAGEMENT OF PURCHASES IN THE PUBLIC SERVICE: A CASE STUDY IN A FEDERAL UNIVERSITY POTIGUAR}

\section{ABSTRACT}

The study aimed to identify which practices of purchases are adopted in the Federal Institutions of Higher Education of the High West Region, in order to investigate the level of efficiency of the management of procedural aspects. To this end, we used the case study that is guided in the application of questionnaires with open and closed questions, in the analysis of content and direct observation. The questionnaires were applied to the servers that act as managers of shopping and also servers to applicants. The assessment of the questionnaires was based on tabulation of data obtained and crossed with the information gathered from the analysis of the administrative structure. Considering 


\section{ISSN - 2447-178X}

the findings, it was noted that, in spite of the routines practiced by UFERSA Campus in Pau dos Ferros if they put in a coherent way, at different stages of the procurement process there are failures in important aspects of the efficiency. These failures may generate consequences associated with the failure of legal devices, the increase in spending, the unnecessary purchases, the lack of materials at the time you need. Being necessary that managers implement policies to remedy these shortcomings and, consequently, provide greater accuracy in the management of public resources directed to this institution.

KEYWORDS: Management of purchases, public sector procurement, organizational efficiency.

\section{INTRODUÇÃO}

Nas últimas décadas, a administração pública vem sofrendo mudanças em suas políticas de gestão que acarretaram reformulações de suas práticas a fim de torná-las mais eficientes, eficazes e efetivas. Muitas dessas mudanças advieram em função da conjuntura econômica, a qual é marcada pelas restrições orçamentárias frente à crescente demanda da sociedade. Desse modo, os gestores públicos têm que cada vez mais planejar e orçar suas ações - observando sempre os aspectos legais. Nesse ensejo, o processo envolvendo as compras públicas destaca-se porque, dentre outros fatores, ele trata diretamente da aplicação e utilização dos recursos públicos.

Seguindo esse entendimento, Feliciano (2016, p. 11) versa que "na busca pela eficiência na administração pública no Brasil, do fazer mais com menos, o gestor público tem o dever de utilizar ferramentas para alcançar a redução dos gastos públicos, buscando assim, o equilíbrio financeiro e orçamentário das contas públicas". Nessa perspectiva, a excelência na gestão dos recursos gerará benefícios diretos para as organizações públicas, reduzindo gastos sem comprometer o nível de serviço observado pelos usuários finais - os cidadãos.

Cabe ressaltar que, segundo Tridapalli, Fernandes e Machado (2011, p. 402), "os gastos com compras de bens e serviços podem representar até $36 \%$ dos orçamentos das unidades governamentais. Assim, cabe ao poder público desenvolver técnicas ou adaptá-las da iniciativa privada e incorporá-las à gestão pública para aumento da eficiência e eficácia desses". Logo, depreende-se que há grande representatividade dos volumes financeiros despendidos pelas instituições públicas no ato de comprar, fato que exige dos gestores o empenho para otimizar essa realização.

Conhecer a gestão das compras nos diversos órgãos e instituições públicas é imprescindível. No âmbito do sistema federal de ensino superior tal processo também se faz necessário tendo em vista que este passou por expansão em todo o país - cerca de 1,180 milhões de alunos na rede em 2014 (VIEIRA, 2016). Em contrapartida, o Ministro da Educação, em entrevista ao jornal Estadão (2016), declarou que os cortes dos investimentos nas universidades federais vêm ocorrendo desde 2014, e para 2017 a previsão é de reduzi-los em até $45 \%$, percentual que em reais representa cerca de 3,5 bilhões (VIEIRA, 2016).

Partindo dos pontos observados, salienta-se a necessidade de investigar como o processo de compras é efetivado nas Instituições Federais de Ensino Superior (IFES) a fim de ratificar se os processos internos adotados mostram-se eficientes. A esse respeito, Oliveira $(2015$, p. 46$)$ afirma que "a melhoria 
da eficiência dessa área pode levar a vantagens competitivas, não só pela redução de custos, mas também pela melhoria do desempenho do processo". Considerando isso, o presente estudo se propõe a analisar o nível de eficiência das práticas de gestão de compras no Campus da Universidade Federal Rural do Semi-Árido em Pau dos Ferros/RN.

É com foco nessa IFES que a pesquisa se propõe a compreender o processo de aquisição de materiais, necessários para seu funcionamento, a fim de evidenciar a importância da manutenção da eficiência nesse ensejo. 0 estudo estimula, ainda, uma reflexão quanto à aplicabilidade do princípio constitucional da eficiência, expressa no artigo 37 da Constituição Federal de 1988 (BRASIL, 1988). Com isso, a contribuição acadêmica visa contemplar a adoção das prerrogativas teóricas da gestão de compras públicas.

\section{REVISÃO BIBLIOGRÁFICA}

\subsection{Compras públicas}

\subsubsection{Aspectos conceituais}

Para que a máquina do Estado funcione é necessário que ela seja suprida com variados tipos de materiais e serviços, tendo em vista a diversidade dos serviços públicos oferecidos no país. Nessa dialética, destaca-se o processo de compra, o qual compreende o pagamento de certo preço em troca de um produto ou serviço, envolvendo o consentimento das partes. De acordo com a Lei no 8.666, de 21 de junho de 1993, Lei de Licitações e Contratos Administrativos (Brasil, 1993), a compra significa "toda aquisição remunerada de bens para fornecimento de uma só vez ou parceladamente". Partindo para o âmbito administrativo, Rosa (2012, p. 96) afirma que:

$\mathrm{O}$ ato de comprar pode ser definido como sendo um conjunto de ações que as organizações devem realizar para comprar todos os produtos e serviços necessários para sua produção e/ou seu funcionamento. Para que seja efetuada a compra, devem ser escolhidos os fornecedores aptos a vender os produtos e os serviços necessários, negociados os preços e as condições de compra, estabelecidos os contratos, elaboradas as ordens de compra, procedidos todos os passos para o correto recebimento dos produtos e serviços comprados e, por fim, pagos os produtos e serviços recebidos.

À vista disso, o processo de aquisição no serviço público representa fator decisivo no planejamento estratégico dessas instituições. Nessa perspectiva, Baily et al. (2000, p. 16) versa que a "compra é vista pela organização bem-sucedida de hoje como uma atividade de importância estratégica considerável". Isso porque a compra gera reflexos tanto na utilização dos recursos, na otimização e eficiência da aplicação desses, quanto na capacidade de afetar diretamente as atividades que as entidades públicas desenvolvem, as quais demandam que ela ocorra na quantidade e momento adequados. 
Os procedimentos e modos de comprar no serviço público estão previstos no arcabouço legislativo do país. A Constituição Federal de 1988, em seu Artigo 37, inciso XXI, expressa que "ressalvados os casos especificados na legislação, as obras, serviços, compras e alienações serão contratados mediante processo de licitação pública que assegure igualdade de condições a todos os concorrentes [...]". Delibera-se, portanto, que as compras públicas em geral devem passar por processo de licitação.

Para tratar especificamente sobre o assunto, o legislador instituiu as normas para licitações e contratos da Administração Pública por meio da Lei nº 8.666, de 21 de junho de 1993 e alterações posteriores. Já a modalidade de pregão, é tratada pela Lei $n^{0} 10.520$, de 17 de julho de 2002 e por decretos de regulamentações. 0 Quadro 1 apresenta as informações sobre os meios possíveis para efetuar as aquisições públicas, conforme as regulamentações das referidas leis.

QUADRO 1: MEIOS UTILIZADOS PARA COMPRAS NO SERVIÇO PÚBLICO.

\begin{tabular}{|l|l|}
\hline FORMAS & CONCEITO \\
\hline Licitação & $\begin{array}{l}\text { É o procedimento administrativo preliminar, mediante o qual a Administração, } \\
\text { baseada em critérios prévios, seleciona, entre várias propostas referentes a } \\
\text { compras, obras ou serviços, a que melhor atende ao interesse público, a fim } \\
\text { de celebrar contrato com o responsável pela proposta mais vantajosa, em } \\
\text { observância ao princípio constitucional da isonomia. Existem quatro tipos de } \\
\text { licitação, que dizem respeito à maneira como ela será julgada, são eles: Menor } \\
\text { Preço; Melhor Técnica; Técnica e Preço; e Maior Lance ou Oferta. Combinado a } \\
\text { isso, a licitação pode ser realizada seguindo diferentes procedimentos, os quais } \\
\text { são delimitados nas seguintes modalidades: Concorrência; Tomada de preço; } \\
\text { Convite; Concurso; Leilão; e Pregão. }\end{array}$ \\
\hline Sistema de Registro de Preço & $\begin{array}{l}\text { É uma ferramenta ao processo de licitação pública na qual a administração } \\
\text { mantém registrado, em ata própria (Ata de Registro de Preços), os produtos } \\
\text { ou serviços com suas especificações, os valores e fornecedores devidamente } \\
\text { habilitados, para contratações futuras. }\end{array}$ \\
\hline Dispensabilidade de Licitação & $\begin{array}{l}\text { Os casos de dispensabilidade de licitação são aqueles que se enquadram em } \\
\text { situações relevantes e, por essa razão, a lei autoriza a exceção ao certame. Esses } \\
\text { casos constam do rol do artigo 24, incs. de I a XXXIII da Lei Federal no 8.666/93. }\end{array}$ \\
\hline Inexigibilidade de Licitação & $\begin{array}{l}\text { Justifica-se nas hipóteses em que se verifica a impossibilidade jurídica da } \\
\text { realização do certame, quer pela natureza do negócio envolvido, quer pelos } \\
\text { objetivos sociais almejados pelo Poder Público. A inviabilidade de competição, } \\
\text { a que se refere a lei, contempla tanto as hipóteses nas quais o fornecedor é } \\
\text { exclusivo (inciso I), quanto aquelas em que o contratado é o único que reúne as } \\
\text { condições necessárias à plena satisfação do objeto do contrato (incisos II e III). }\end{array}$ \\
\hline Fonte: Adaptado de ENAP (2015).
\end{tabular}

Considerando o exposto, observa-se que a normatização dos meios possíveis para realização de compras no setor público preocupou-se em assegurar o cumprimento do princípio constitucional da isonomia e da seleção da proposta mais vantajosa para a Administração, tornando esse processo impessoal ao sobrepor o interesse público. Dessa forma, cabe aos gestores o planejamento das compras de modo a conciliar as deliberações expressas em lei com as demandas dos solicitantes sem acarretar prejuízos na prestação do serviço público. 


\subsubsection{0 papel do setor e do gestor de compras}

O ciclo de compras de uma instituição pública envolve diversos atores. Dentre eles, destaca-se o setor de compras, os gestores de compras e os clientes. A otimização da execução dos procedimentos inerentes à atividade de compras, desde a identificação da demanda e solicitação até a entrega do material requisitado, exige que os processos internos sejam eficientes de modo a resultar na sinergia dos envolvidos.

Segundo Rosa (2012 p. 96), o setor de compras de uma entidade pública "é responsável pelo ato de comprar". Ainda de acordo com o autor, o principal objetivo desse setor "é conseguir comprar todos os produtos e serviços necessários para a produção e o funcionamento da organização, que tenham a melhor qualidade possível, a quantidade correta no prazo estabelecido pela área solicitante da organização, com preço compatível com o mercado". Trata-se, por conseguinte, da intermediação entre os clientes do setor e os fornecedores dos materiais demandados.

Batista e Maldonado (2008, p. 686) definem que os clientes do setor de compras "são todos que, direta ou indiretamente, necessitam adquirir produtos e/ou serviços para alcançar os resultados almejados. Para isso, é necessário que todos estejam imbuídos e engajados na melhoria do sistema como um todo e, por conseqüência, na maximização dos resultados esperados". Tal concepção indica que os procedimentos efetivados pelo setor serão determinantes para a satisfação desses clientes e dos usuários finais do serviço público.

Nessa perspectiva, o gestor de compras ganha destaque, uma vez que o setor perpassa a visão de burocrático e engessado para estratégico e gerador de resultados numa organização. A esse respeito Rosa (2012) versa que:

\footnotetext{
Os profissionais do Setor de Compras devem evoluir para acompanhar as necessidades do setor, devem ser pessoas bem informadas, atualizadas, além de terem habilidades interpessoais, como poder de negociação, facilidade de trabalhar em equipe, boa comunicação, capacidade de gestão de conflitos e amplo conhecimento de logística. Devem ter a percepção de que a função do setor é fonte geradora de lucro/benefícios para a organização, acreditar que o setor pode e deve contribuir para o planejamento estratégico da organização, portanto, possuir visão de longo prazo. Assim, o Setor de Compras é vital para o sucesso da organização e suas contribuições podem apoiar de forma decisiva os planos e as políticas corporativas.
}

Seguindo essa mesma linha de raciocínio, Almeida Jr. (2012, p. 58), afirma que "profissionais competentes na área de compras podem dar uma contribuição efetiva para a saúde da empresa". Ante o exposto, fica claro o entendimento de que o processo de compras, incluindo seus envolvidos, é também determinante para que os serviços públicos sejam satisfatórios aos seus usuários. Além disso, esse aspecto possui relevância no que tange à aplicação dos recursos públicos, os quais são cada vez mais escassos frente às demandas crescentes. 


\subsection{Gestão do processo logístico}

As atividades de logística se direcionam no sentido de planejar de forma harmônica os processos que antecedem a compra até a disponibilização dos produtos/serviços aos usuários finais. Nesse sentido, Juttner (2005, p. 13) discorre que esses processos se dão "com o objetivo de assegurar que o produto chegue ao destino final no momento solicitado, na quantidade correta e a um custo viável". Desse modo, fica visível o papel estratégico de destaque desempenhado pela análise e planejamento logístico nas diversas organizações, inclusive as públicas. Seguindo essa perspectiva, Novaes (2001, p. 37) disserta que a logística contemporânea compreende:

A definição e o cumprimento dos prazos ao longo de toda a cadeia; a integração efetiva e sistêmica de todos os setores da empresa; o estabelecimento de parcerias com fornecedores e clientes, sejam eles externos ou internos; a busca da racionalização dos processos e da redução dos custos em toda a cadeia de suprimentos; a satisfação plena do cliente e a manutenção de um nível de serviço adequado.

Apesar de não haver competitividade no serviço público, é necessária a adoção de práticas logísticas, uma vez que esta acarretará redução de custos operacionais, otimização dos processos, aprimoramento do desempenho dos servidores e, consequentemente, da qualidade do serviço oferecido. Segundo Bowersox et al. (2014, p. 34) "alcançar o menor custo total significa que os ativos financeiros e humanos aplicados na logística devem ser mínimos. Também é necessária para manter as despesas operacionais no nível mais baixo".

Ainda nesse sentido, Tridapalli, Fernandes e Machado (2011, p. 409) explanam que "assim como na iniciativa privada, é importante ter no setor público sistemas de gestão logística, construídos a partir da utilização das ferramentas de governo eletrônico com incorporação de técnicas, processos e princípios extraídos da iniciativa privada". No âmbito da cadeia de compras públicas, a logística está diretamente relacionada com o setor responsável pelo ato de comprar, o qual, segundo Rosa (2012, p. 96), deve "conseguir comprar todos os produtos e serviços necessários para a produção e o funcionamento da organização, que tenham a melhor qualidade possível, a quantidade correta no prazo estabelecido pela área solicitante da organização, com preço compatível com o mercado".

Nessa concepção, cabe avultar que, para o alcance de um desempenho logístico superior, o processamento eficiente das informações acuradas é de extrema importância (BOWERSOX et al., 2014). Além disso, as atividades de compras devem estar alinhadas com os demais envolvidos nesse processo, de modo a harmonizar, sincronizar e integrar as ações. Tais perspectivas estão engajadas ao entendimento de Rosa (2012 p. 97) de que o setor de compras "deve interagir intensamente com os demais departamentos da organização, recebendo e processando informações, bem como os alimentados de informações úteis para às suas tomadas de decisão". Dessa forma, torna-se possível a boa execução do processo compras, que representará um fator de sucesso à economicidade e à melhoria da execução das atividades, além de impactar positiva e diretamente o usuário final. 


\subsection{Princípio da eficiência no serviço público}

Cada vez mais os objetivos da gestão privada e da pública estão convergindo. Uma das sinalizações disso foi a inclusão o princípio da eficiência no caput do artigo 37 da Constituição Federal através da Emenda Constitucional n 19, de 04 de junho de 1998. Diante disso, faz-se imprescindível compreender a eficiência como princípio da Administração Pública. Nos vocabulários, a definição do termo "eficiência" está associado à capacidade de realizar algo para atingir determinado objetivo. No entanto, no arcabouço conceitual da Administração a competência de execução dos meios e a competência dos fins são conceituadas com diferentes vocábulos, conforme expressa Chiavenato (1998, p. 47):

A eficiência está voltada para a melhor maneira (the best way) pela qual as coisas devem ser feitas ou executadas (métodos), a fim de que os recursos (pessoas, máquinas, matérias-primas) sejam aplicados da forma mais racional possível. A eficiência preocupa-se com os meios, com os métodos e procedimentos mais indicados que precisam ser devidamente planejados e organizados a fim de assegurar a otimização da utilização dos recursos disponíveis. A eficiência não se preocupa com os fins, mas simplesmente com os meios. 0 alcance dos objetivos visados não entra na esfera de competência da eficiência; é um assunto ligado à eficácia. À medida que o administrador se preocupa em fazer corretamente as coisas, ele está se voltando para a eficiência (melhor utilização dos recursos disponíveis). Porém, quando ele utiliza estes instrumentos fornecidos por aqueles que executam para avaliar o alcance dos resultados, isto é, para verificar se as coisas bem feitas são as que realmente deveriam ser feitas, então ele está se voltando para a eficácia (alcance dos objetivos através dos recursos disponíveis).

Além de a eficiência e a eficácia se referirem a ações distintas, a existência de uma delas não acarreta na consecução da outra, isto é, uma organização pode ser eficiente sem que seja eficaz e viceversa. Tal proposição é observada por Daft (1999, p. 39) ao expor que "às vezes a eficiência conduz à eficácia. Em outras organizações, eficiência e eficácia não são relacionadas. Uma organização pode ser altamente eficiente e não conseguir seus objetivos [...]. De maneira análoga, uma organização pode alcançar suas metas de lucros, mas ser ineficiente".

Diante do exposto, pode-se inferir que a operacionalização no serviço público não está necessariamente preocupada com o atingimento dos resultados, uma vez que a legislação faz menção apenas à eficiência. No entanto, apesar de haver essa dicotomia na literatura, depreende-se que tais termos são indissociáveis, seguindo a percepção compartilhada por Cunha e Ruiz (2008, p. 476) de que "o aludido comando constitucional está a exigir as duas coisas, obrigando uma atuação estatal apoiada na otimização dos meios e na luta constante por melhores resultados institucionais".

Nessa conjuntura, destaca-se que o Princípio da Eficiência exige que as ações administrativas sejam executadas com prontidão, apuro e rendimento funcional. Por se tratar do mais moderno princípio da função administrativa, a qual não mais se satisfaz em ser exercida apenas com legalidade, 
reivindicando resultados positivos para o serviço público e satisfatório cumprimento das necessidades da sociedade e de seus membros (MEIRELLES, 2002).

\section{METODOLOGIA}

A presente pesquisa é do tipo estudo de caso e se pauta no método quantitativo que, segundo Rampazzo (2005, p. 58), "se inicia com o estudo de um certo número de casos individuais, quantifica fatores segundo um estudo típico, servindo-se frequentemente de dados estatísticos, e generaliza o que foi encontrado nos casos particulares". Esse enquadramento se dá em razão do objetivo e da necessidade de identificação das práticas inerentes ao processo de compras adotadas pelas universidades federais através da percepção dos servidores lotados no Setor de Compras e dos solicitantes. A referida abordagem possibilitará o exame dos elementos que influenciam os alvos do estudo quanto aos fatores que condicionam a eficiência das aquisições públicas.

No que diz respeito aos objetivos, a pesquisa classifica-se como do tipo descritiva. De modo que, para reunir informações sobre o funcionamento do setor de compras e dos métodos adotados para o processamento das aquisições institucionais, foram levantadas questões a fim de caracterizar tais aspectos. Além disso, buscou-se pelos solicitantes, procurando identificar a percepção deles, como beneficiários finais, quanto à satisfação da atual rotina. Para tanto, o estudo valeu-se da técnica de aplicação de questionários estruturados direcionados aos diferentes atores envolvidos nesse processo, os quais foram construídos com base nas discussões apresentadas no Quadro 2.

QUADRO 2: DEFINIÇÃO DOS INDIVÍDUOS E DOS OBJETIVOS DOS QUESTIONAMENTOS

\begin{tabular}{|c|c|c|}
\hline ALVOS & FINALIDADE & FONTE \\
\hline \begin{tabular}{l} 
S e r v i d o r e s \\
Gestores de \\
\multicolumn{2}{c}{ Compras }
\end{tabular} & $\begin{array}{l}\text { Indagar sobre aspectos procedimentais das aquisições a fim de compreender e } \\
\text { avaliar as práticas adotadas. O questionário foi dividido nas seguintes dimensões: } \\
\text { - Dimensão Conceitual: tem como objetivo levantar informações sobre as } \\
\text { capacidades técnicas dos gestores; } \\
\text { - Dimensão Procedimental: objetiva evidenciar dados sobre aspectos práticos } \\
\text { envolvidos no ato de compras. } \\
\text { - Dimensão Avaliação: força os gestores a avaliar as práticas adotadas como um } \\
\text { todo, inclusive a participação dos solicitantes. }\end{array}$ & $\begin{array}{l}\text { F E L I C I A N O } \\
\text { (2016); } \\
\text { H E G E N B E R G } \\
(2013) ; \\
\text { ROSA (2012). }\end{array}$ \\
\hline $\begin{array}{l}\text { S e r v i d o r e s } \\
\text { Requisitantes }\end{array}$ & $\begin{array}{l}\text { Identificar o nível de satisfação dos servidores com as rotinas de compras da } \\
\text { universidade, de conhecimento dos processos internos e a prática de planejamento. }\end{array}$ & MELO (2012). \\
\hline
\end{tabular}

O questionário foi estruturado em blocos compostos de perguntas fechadas e abertas. Nessa perspectiva, o processo de coleta ocorreu mediante a aplicação de formulários impressos que continham o objetivo da pesquisa bem como da manutenção do sigilo e privacidade dos dados coletados. Os entrevistados possuíram a liberdade de responder ou não ao questionário, os quais totalizarão 116 pessoas consultadas, o universo da pesquisa, entre gestores de compras e requisitantes, conforme expõe-se no Quadro 3. A definição da instituição investigada (UFERSA Campus Pau dos Ferros) foi do tipo "não-probabilística" (GIL, 1999). A escolha levou em conta critérios de localização, características e disponibilidade dos servidores em participar do estudo. 
QUADRO 3: SERVIDORES ENTREVISTADOS.

\begin{tabular}{|c|c|c|}
\hline SERVIDORES & QUANTIDADE & RESPONDENTES \\
\hline Gestores de Compras & 03 & 03 \\
\hline Servidores Docentes e Técnicos Administrativos & 113 & 67 \\
\hline
\end{tabular}

Fonte: Dados da pesquisa (2017).

A coleta de dados foi realizada na segunda semana de setembro de 2017 através de questionário impresso. No total, obteve-se a participação dos 3 gestores e de 67 solicitantes. Considerando o número de solicitantes existente, admitiu-se o erro amostral em até $10 \%$ e $95 \%$ de nível de confiança. Dessa forma, o número de participantes superou o número mínimo aceitável de 53 respondentes (SANTOS, 2017). Finalizada a coleta dos dados, procedeu-se com a classificação e codificação dos achados, mediante a utilização de planilhas no Microsoft Excel. Isso permitiu agrupar os tópicos de cada bloco pesquisado em função das definições, propriedades e dimensões obtidas.

\section{RESULTADOS E DISCUSSÕES}

\subsection{Contextualização sobre a UFERSA Campus Pau dos Ferros}

A IFES foco do presente estudo está situada na cidade de Pau dos Ferros, na região do Alto Oeste Potiguar. A escolha por essa instituição considerou a sua importância no âmbito da interiorização da educação superior pública, tendo em vista a sua localização, como também a possibilidade de acesso às informações necessárias para atingimento dos objetivos propostos. A missão, princípios e objetivos dessa universidade são apresentados no Quadro 4.

QUADRO 4: MISSÃO, PRINCÍPIOS E OBJETIVOS DA INSTITUIÇÃO ESTUDADA.

\begin{tabular}{|c|c|}
\hline MISSÃO & $\begin{array}{l}\text { Produzir e difundir conhecimentos no campo da educação superior, com ênfase para a região Semiárida } \\
\text { brasileira, contribuindo para o desenvolvimento sustentável e o exercício pleno da cidadania, mediante } \\
\text { formação humanística, crítica e reflexiva, preparando profissionais capazes de atender demandas da } \\
\text { sociedade. }\end{array}$ \\
\hline PRINCÍPIOS & $\begin{array}{l}\text { I - Ética, gestão democrática, transparência, participação, legalidade, legitimidade, economicidade, } \\
\text { impessoalidade, moralidade, publicidade, eficiência e sustentabilidade; } \\
\text { II - Descentralização administrativa e acadêmica; III - Natureza pública e gratuita do ensino, sob a } \\
\text { responsabilidade da UniãWo; } \\
\text { IV - Liberdade de ensino, pesquisa e extensão e difusão e socialização do saber; } \\
\text { V - Indissociabilidade entre o ensino, a pesquisa e a extensão; } \\
\text { VI - Democratização da educação no que concerne à gestão, à igualdade e oportunidade de acesso e à } \\
\text { socialização de seus benefícios. }\end{array}$ \\
\hline OBJETIVOS & $\begin{array}{l}\text { I - Ministrar ensino superior visando ao desenvolvimento político, científico, social, ambiental e } \\
\text { econômico do indivíduo e da sociedade; } \\
\text { II - Promover a pesquisa e a investigação científica, com vistas à produção e difusão do conhecimento; } \\
\text { III - Estabelecer diálogo permanente com a sociedade de forma a contribuir para a solução dos problemas } \\
\text { sociais, ambientais, econômicos e políticos, dando ênfase à região Semiárida brasileira. }\end{array}$ \\
\hline
\end{tabular}




\title{
ISSN - 2447-178X
}

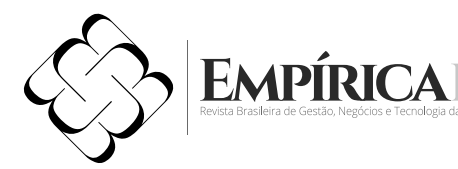

No que diz respeito ao surgimento da UFERSA Campus Pau dos Ferros, de acordo com o Portal da instituição, esse se deu a partir da adesão da UFERSA ao Plano de Reestruturação e Expansão das Universidades Federais (REUNI), o qual foi uma das ações do Plano de Desenvolvimento da Educação (PDE) que teve como objetivo:

\begin{abstract}
“Proporcionar às Universidades Federais condições necessárias para a ampliação do acesso e permanência dos alunos no ensino superior; e considerando a necessidade de promover a interiorização da educação superior pública federal no Estado do Rio Grande do Norte, como fonte propulsora do desenvolvimento econômico sustentável com inclusão social, a UFERSA solicitou ao Ministério da Educação (MEC) a implantação do Campus Pau dos Ferros" (PORTAL DA UFERSA, 2014).
\end{abstract}

Nesse ensejo, o Campus Pau dos Ferros, em abril de 2012 tem a sua criação pactuada junto ao MEC (Ministério da Educação), com autorização para a criação e funcionamento dos Cursos de Bacharelado em Ciência e Tecnologia Integral e Noturno. Atualmente, o Campus dispõe de 7 cursos (Arquitetura e Urbanismo, Bacharelado em Ciência e Tecnologia, Engenharia Ambiental e Sanitária, Engenharia Civil, Engenharia da Computação, Engenharia de Software, e Tecnologia da Informação), e cerca de 1.130 alunos matriculados. Para tanto, ela conta com o apoio de 75 servidores docentes, 41 servidores técnicos administrativos, 26 funcionários terceirizados e uma estrutura física que é composta por: um bloco administrativo, um bloco de sala de professores, dois blocos de salas de aulas, uma biblioteca, um centro de convivência, um auditório, uma garagem, e um almoxarifado.

\subsection{DESCRIÇÃO DO PROCESSO DE COMPRAS}

Acerca do processo de compra, esse ponto chama a atenção para a compreensão sobre como o Campus se organiza e funciona diante dos aspectos procedimentais e burocráticos exigidos pela legislação. Nesse sentido, Oliveira (2015, p. 82) destaca que "a realização do processo de compras é uma etapa de grande relevância para qualquer instituição e o seu procedimento deve ser rápido e eficiente. Nele, deve-se evitar o desperdício de recursos e de tempo".

$\mathrm{Na}$ instituição estudada, esse processo transcorre, de modo geral, em quatro momentos diferentes: duas fases internas ao Campus e duas externas, que é efetivada na Sede da UFERSA em Mossoró. Cada uma dessas fases se subdivide em outras para que uma solicitação de compra seja efetivada, envolvendo a passagem por vários setores. A Figura 1 ilustra de forma sistematizada como se dá a divisão de atividades. 


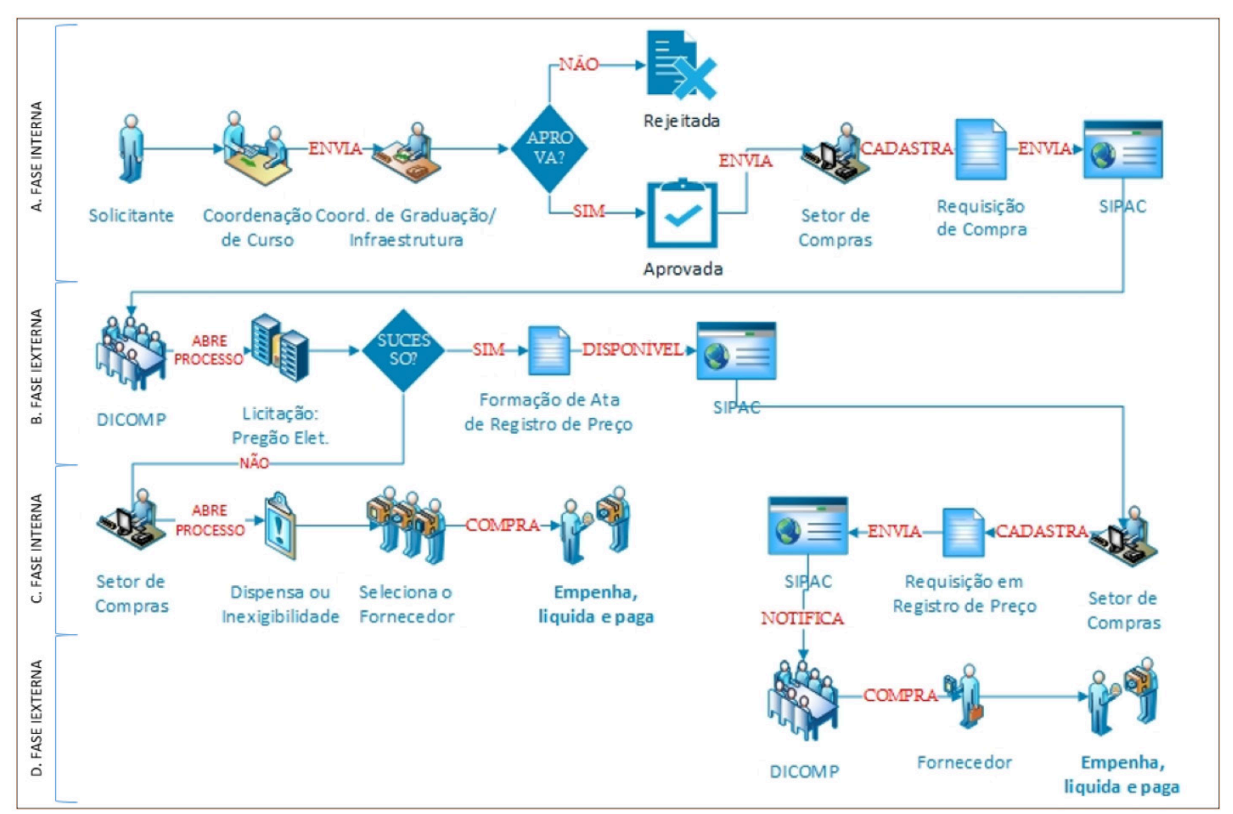

Figura 1: Fases do processo de compras da UFERSA Campus Pau dos Ferros

Fonte: Dados da pesquisa (2017).

Conforme representação na Figura 1, o processo de compra inicia-se por meio da solicitação formal dos servidores. Ela se dá através da entrega de um Formulário de Solicitação de Compra, o qual contém a denominação e descrição do material, o código que o material possui no Catálogo de Materiais SIPAC (Sistema Integrado de Patrimônio Administração e Contratos), sistema utilizado como ferramenta de gerência nesse processo, a quantidade desejada e as cotações de preços (no mínimo três). Além disso, entrega-se a Justificativa de Compra, documento em que o solicitante expressa a justificativa da necessidade do material, da quantidade pedida e dos possíveis prejuízos caso o item não seja adquirido.

No caso dos docentes, essa documentação passa pelo coordenador de seu respectivo curso, que filtra as demandas e, em seguida, encaminha elas ao Coordenador de Graduação para aprovação ou não da compra, considerando os recursos disponíveis. Caso a resposta seja positiva, a documentação é entregue ao Setor de Compras. Já para os técnicos, o Coordenador de Infraestrutura é o encarregado de reunir as demandas, de aprová-las e de repassá-las ao Setor. Esse cenário, se executado de modo correto, apresenta-se como uma forma de gerenciamento logístico das demandas ao se filtrar a necessidade de aquisição e a existência dos recursos para efetuar o pedido de compra. Em contrapartida, tal fato exige "a coordenação das diferentes atividades componentes da logística, tornando-as um conjunto harmonioso que visa a obter os menores custos logísticos que atendam ao Nível de Serviço" (ROSA, 2012, p. 15).

O Setor de Compras de posse desses documentos realiza a Requisição de Compra e a envia através do SIPAC, para a Divisão de Compras (DICOMP) que fica na Sede da UFERSA. A DICOMP reúne todas as demandas da UFERSA (da sede e dos três Campus) para realizar a licitação na modalidade de pregão Eletrônico e, assim, formar uma Ata de Registro de Preço com os fornecedores que ofereceram a proposta mais vantajosa. 0 recebimento das solicitações, via de regra, são realizadas anualmente 
por meio de abertura de Calendário de Compras, o que exige um planejamento de longo prazo para os solicitantes. Caso o material solicitado não seja contemplado através do Pregão, o Setor de Compras analisa a possibilidade da realização de Dispensa ou Inexigibilidade de Licitação, observando sempre as prerrogativas legais.

O fato de haver uma junção das demandas da UFERSA como um todo demonstra a preocupação no barateamento da compra. Isso por que o volume maior de compra, em tese, tende a baixar o preço, teoricamente. No entanto, cobra dos servidores maior planejamento de previsão de demandas, uma vez que para realizar essa reunião é exigido maior tempo sendo que, em contraponto, as demandas por determinado material ou equipamento não podem ser sincronizadas.

Formada a Ata de Registro de Preço, dentro de seu prazo de validade, o SIPAC notifica o saldo que o Campus possui em consonância com o informado na Requisição de Compra, que estará disponível para Requisição em Registro de Preço. É importante destacar que a formação dessa Ata não obriga a compra, indicando apenas a possibilidade de compra. Por meio dessa requisição o Campus solicita efetivamente a compra dos materiais via SIPAC, necessitando da autorização prévia do ordenador de despesa, no caso do Campus, o Diretor.

As fases seguintes de empenho, liquidação e pagamento são feitas pelos servidores da DICOMP. Quando da entrega, o aceite é realizado pelo solicitante ou seu representante, que é notificado de que o material pedido encontra-se na UFERSA em Mossoró, aguardando que ele vá até a sede para conferir se o item solicitado foi devidamente entregue pelo fornecedor.

Conforme exposto, as atividades do processo de compras desenvolvidas no Campus dizem respeito, basicamente, às relacionadas à previsão de demandas, à definição do que será adquirido e consequentemente à aplicação dos recursos, as quais serão passadas para a Sede dar sequência ao processo. 0 contato com fornecedores só é feito quando da realização de dispensa ou inexigibilidade. No entanto, tal fato não diminui a importância das práticas desenvolvidas pela instituição. Tal perspectiva corrobora com o pensamento de Melo (2012, p. 64), ao indicar que no extenso processo de compras quatro atividades se avultam e influenciam o sucesso da compra pública, sendo elas: "o planejamento da compra que envolve a mensuração das necessidades, a descrição correta do objeto, a prospecção de cotações (orçamentos) e a colocação no tempo certo".

Dessa forma, destaca-se que sem a observância desses quatro elementos, que são sinalizadores importantesna determinação do queequandocomprar,oprocessodeaquisiçãotendeasercomprometido, uma vez que ele se tornará ineficiente e, consequentemente, não pautado na economicidade. Além disso, esses elementos recebem maior relevância ao se considerar que no processo de compra pública o meio a ser utilizado (licitação e suas modalidades, dispensa e inexigibilidade de licitar) é regido pela legislação, sobrando no tocante ao planejamento a grande ferramenta passível de aprimoramento pelos gestores.

\subsection{Gestores de compras}

No que diz respeito à análise e ao diagnóstico das práticas executadas no âmbito das aquisições, os gestores de compra recebem destaque, isso porque eles devem deter a percepção sobre como 
se opera todo o processo a fim de permitir a reunião de informações pertinentes, e com isso possa identificar qual o melhor caminho e momento em que as atividades devem ser desenvolvidas. Tal perspectiva corrobora com o entendimento de Melo (2012, p. 64) ao afirmar que "antes de chegar na fase do pregão eletrônico é fundamental que as fases anteriores tenham sido executadas com qualidade, garantindo assim a melhor aquisição para a administração pública".

Atualmente, a instituição estudada possui três servidores ligados diretamente ao processo de compras, os servidores que estão lotadas no Setor de Compras. Os dados levantados demostram que esses gestores estão a pouco tempo desempenhando essa função, dois deles estão há até um ano, e o outro há três anos. Além disso, identificou-se que, $66,7 \%$ dos respondentes afirmaram ter participado de apenas 1 curso de capacitação, já os 33,3\% participaram de dois. Tal perspectiva espelha no tocante à necessidade de atualização e qualificação para atuar na área, em que 66,7\% dos participantes indicaram que acredita que a atualização dos seus conhecimentos técnicos é necessária e boa, porém insuficiente, enquanto que $33,3 \%$ dos respondentes afirmaram que ela é necessária, porém ruim e insuficiente.

Quando questionados sobre o nível de conhecimento em assuntos-chave para desempenhar o papel de gestor de compras, obteve-se um resultado bastante desapontador, evidenciando a necessidade de maior investimento em capacitação. 0 nível de conhecimento desses servidores em assuntos diretamente ligados à compra pública é ilustrado na Figura 2.

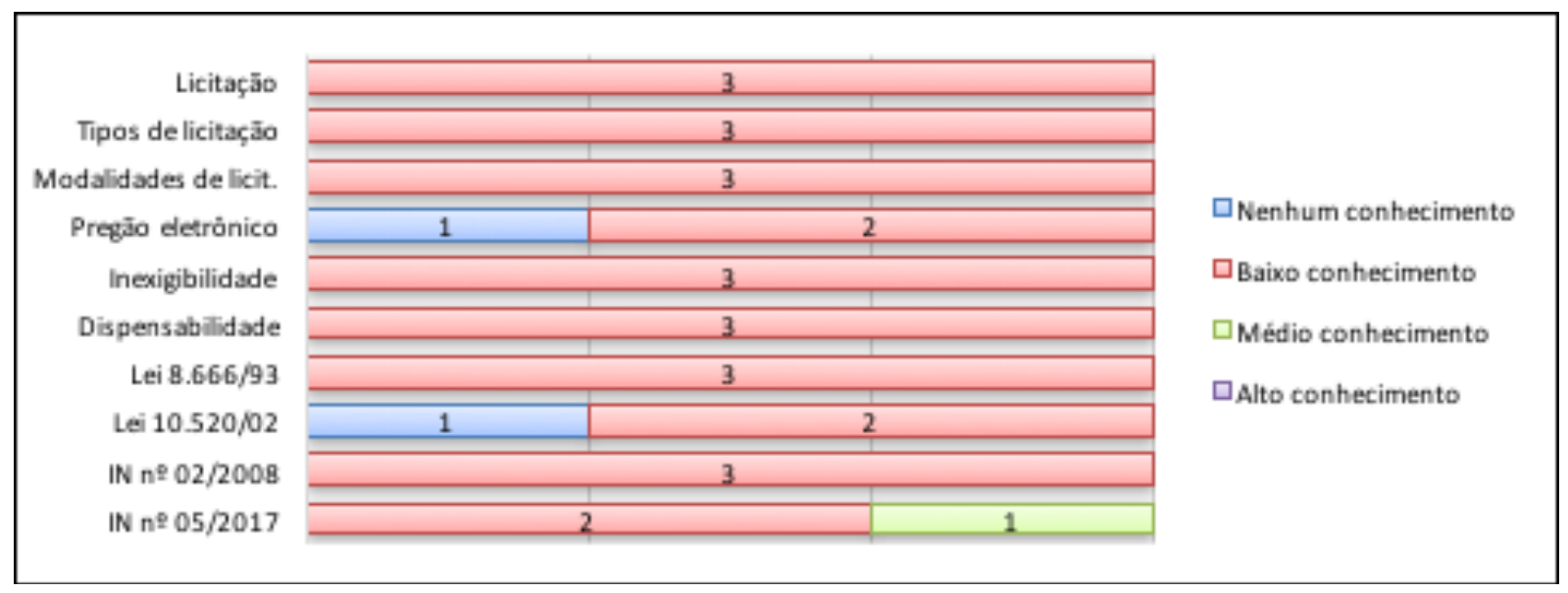

Figura 2: Nível de conhecimento dos gestores de compras da legislação e normas de compras.

Fonte: Dados da pesquisa (2017).

De acordo com Rosa (2012, p. 98) "o comprador deve ter uma base muito sólida da legislação vigente e atualizar-se constantemente, pois todo o sucesso de compras no setor público depende desse quesito". Tal vertente é insuficiente na IFES estudada, visto que é evidente o baixo nível de conhecimento nos assuntos abordados na questão.

No que se refere à Dimensão Procedimental, esta visou identificar aspectos ligados às práticas em si, envolvendo a comunicação e a atuação dos gestores e solicitantes, na percepção daqueles. Considerando as respostas obtidas, constatou-se que o Setor de Compras não dispõe de um manual 
e que os gestores de compras consideram que a linguagem utilizada nos processos de compras é parcialmente compreendida com facilidade por todos os solicitantes. Em relação ao processo comunicativo, a maioria acredita qu e as reuniões junto aos solicitantes são necessárias, porém insuficientes, e que os dados extraídos pelo setor em relação às demandas de compras são necessários e disponibilizados à chefia.

O cenário observado indica a necessidade de aprimoramento na comunicação junto aos solicitantes, e da formalização das atividades desenvolvidas, por exemplo, através de elaboração de manual. Tal fato fragiliza o processo, já que é por meio dessa interação que as partes envolvidas podem mitigar as possíveis falhas. A esse respeito Batista e Maldonado (2008, p. 688) afirmam que as opiniões e sugestões dadas dos solicitantes "contribuem e motivam os atores envolvidos, além de aperfeiçoar os aspectos técnicos, provocando um constante aperfeiçoamento dos métodos e das atividades de compras". Em contrapartida, o ato de disponibilizar informações úteis à chefia se apresenta como ponto positivo, já que estas poderão vir a fomentar as tomadas de decisão.

Em relação aos procedimentos internos, os gestores indicaram que existe uma política/ planejamento para a efetivação das compras, definida pela alta administração do Campus, e que há um plano de ação para cumprimento de prazos em relação às compras, os quais envolveu desde a alta administração até os usuários finais para determinação. Ainda nesse âmbito, constatou-se que, além da legislação, instrumentos como cursos, fóruns e manuais são utilizados para determinar os procedimentos das compras. Em relação a transparência dos processos, os gestores afirmaram que eles são claramente divulgados junto à comunidade usuária.

No que diz respeito à realização de filtros e revisões de demandas de compras, os respondentes afirmaram que ela existe, mas é deficitária. Tal reflexo é observado nos procedimentos de análises de gastos e priorização de compras, que necessitam de aprimoramento. As respostas dos gestores sinalizam que eles buscaram realizar um estudo visando à compreensão do nível de eficiência do processo de compras e a identificação de lacunas solucionáveis, que culminou na determinação de uma metodologia/estratégia definida dos procedimentos de compras.

Rosa (2012), em sua obra, elenca pontos a serem observados no âmbito da logística de compras os quais são capazes de aprimorar o seu funcionamento. De modo geral, os critérios elencados pelo autor contribuem para o aprimoramento dos processos, os quais envolvem as funções administrativas (planejamento, organização, direção e controle). Apontamentos nesse sentido foram questionados e podem ser observados na Figura 3. 


\section{ISSN - 2447-178X}
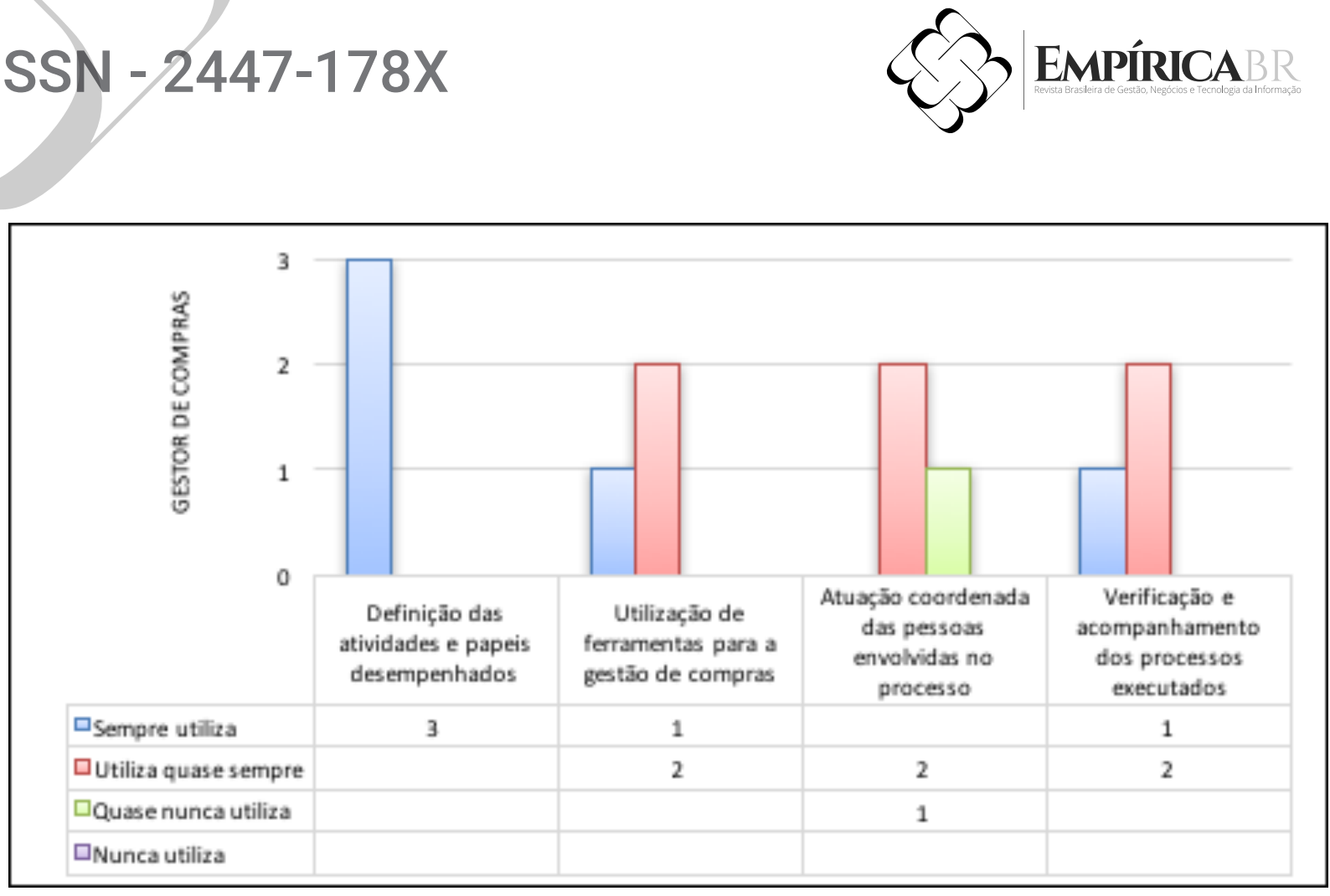

Figura 3: Práticas administrativas utilizadas no processo de compras.

Fonte: Dados da pesquisa (2017).

Conforme pode ser observado na Figura 3, as práticas no tocante ao planejamento, organização, direção e controle que foram questionadas estão presentes no processo de compras da instituição estudada. A esse respeito, Chiavenato (1998, p. 47) afirma que "à medida que o administrador se preocupa em fazer corretamente as coisas, ele está se voltando para a eficiência (melhor utilização dos recursos disponíveis)". Tendo em vista esse entendimento juntamente com os dados coletados, é possível vislumbrar que o campus estudado atingiu uma posição razoável, considerando o pouco tempo de existência.

De modo geral, os gestores lotados no Setor de Compras julgam que as atuais práticas possibilitam parcialmente que os solicitantes de materiais possam calcular o momento no qual eles devem colocar um pedido a fim de repor o item. Avaliando que o processo de compra, do pedido até a entrega do material, no Campus Pau dos Ferros mostra-se satisfatório. No entanto, quando questionados sobre a utilização dos itens solicitados, o Setor afirma que poucas vezes é assegurado que os produtos foram utilizados conforme expressos na solicitação.

Além dos gestores, os requisitantes são atores que impactam diretamente a fluidez do processo de compra, por isso torna-se necessário avaliar o desempenho desses indivíduos nas atividades incumbidas a eles. Os dados indicam bastantes pontos falhos no que tange à execução das atividades de responsabilidade dos requisitantes. Dentre elas, cabe salientar a necessidade de maior planejamento das demandas, considerando a existência certas burocracias indissociáveis a esse processo as quais exigem o ato de planejar, da mesma maneira que os benefícios que tal prática traz, como a utilização racional dos recursos disponíveis. Outro fator importante que está sendo negligenciado é a falta de capacitação direcionada aos solicitantes, isso porque a ausência de conhecimento tende a causar entraves no decorrer do processo. A Figura 4 apresenta a percepção dos gestores sobre a atuação desses indivíduos na instituição estudada. 


\section{ISSN - 2447-178X}

Os solicitantes planejam suas demandas a curto prazo.

Os solicitantes planejam suas demandas a médio e longo prazo.

O fator determinante dos pedidos é a necessidade, sendo desconsiderados outros fatores.

Os fatores determinantes dos pedidos são a necessidade, o custo-benefício e a qualidade.

Ao planejar suas demandas, atenta-se para o aspecto da economicidade

Agem de modo a oferecer total condiçăo para tornar o processo de compras eficiente.

As unidades solicitantes estão capacitadas e não representam uma barreira no processo das compras.

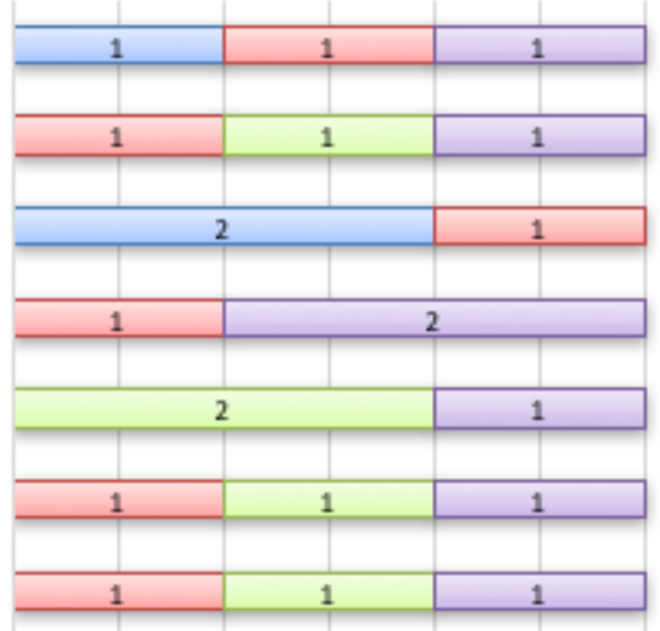

$\square$ Concordo totalmente. $\square$ Concordo parcialmente. $\square$ Discordo parcialmente $\square$ Discordo totalmente.

Figura 4: Avaliação dos solicitantes na percepção dos gestores de compras.

Fonte: Dados da pesquisa (2017).

Diante do exposto, constatou-se a necessidade de aprimoramento em pontos cruciais no tocante aos procedimentos internos de compras, com destaque à esfera do planejamento, dos controles, de capacitação e de comunicação interna. Essas melhorias são fundamentais para que o Campus se torne mais eficiente. Tal perspectiva segue o entendimento de Batista e Maldonado (2008, p. 686) ao versar que "o modelo de desenvolvimento organizacional eficiente passa, necessariamente, pela melhoria dos processos internos de gestão, e pela definição de um modelo de sistema de informação capaz de otimizar os processos e procedimentos relativos às compras".

\subsection{SOLICITANTES DE COMPRAS}

A fim de examinar o nível de satisfação dos solicitantes e de apropriação de conhecimento sobre os processos das compras, aplicou-se um questionário junto aos requisitantes de compras da UFERSA Campus Pau dos Ferros, o qual continha indagações no tocante ao contato do servidor com o Setor de Compras, ao conhecimento dos processos executados e ao planejamento.

Dos 67 solicitantes respondentes, identificou-se que $48 \%$ deles nunca entraram em contato com o Setor de Compras. Dos $52 \%$ que já necessitaram dos serviços do setor (35 solicitantes), 36\% avaliaram que a dificuldade no preenchimento da documentação necessária para efetuar a compra de dificuldade média. A Figura 5 representa os dados obtidos nesse quesito. 


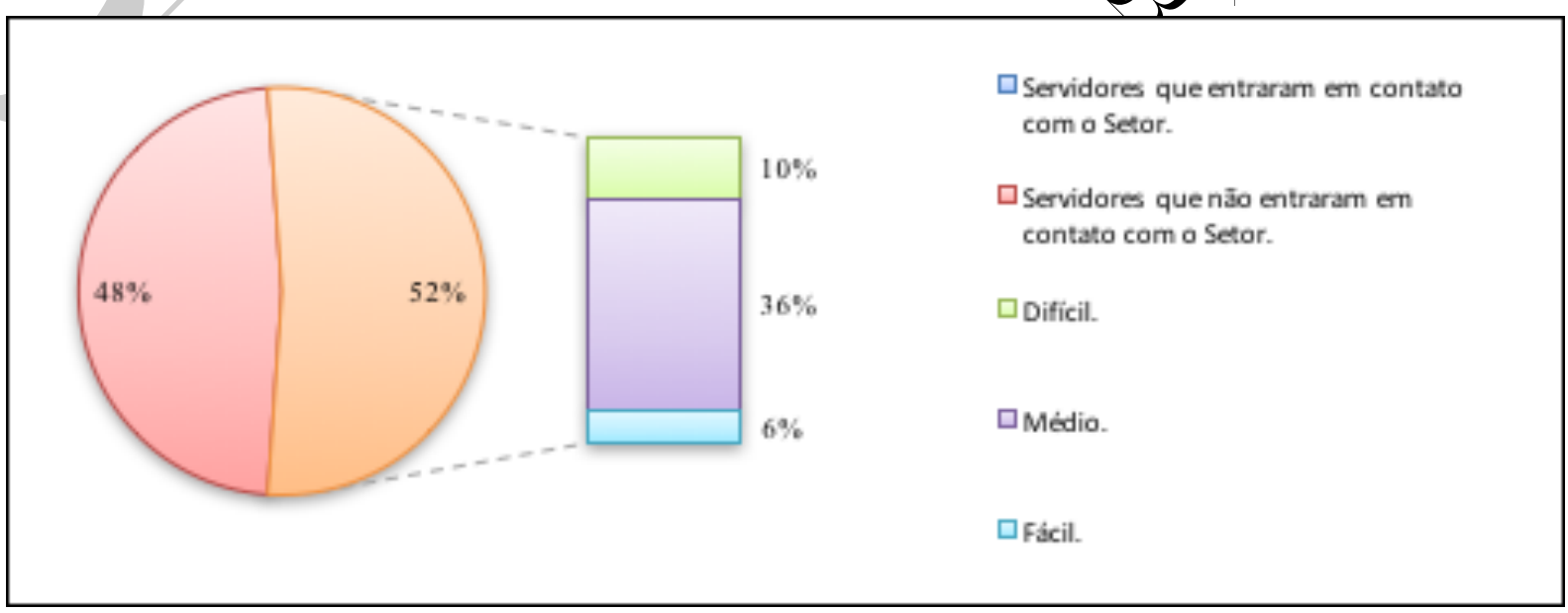

Figura 5: Contato dos solicitantes com o Setor de Compras e nível de dificuldade encontrada.

Fonte: Dados da pesquisa (2017).

Quanto à razão desse contato, dos 35 solicitantes que em algum momento contatou o Setor, 4 solicitaram orientações sobre procedimentos de compra; 1 precisou de orientações sobre procedimentos de compra e orientações sobre a justificativa, formulário de compra e cotação de preço; 3 requereram orientações sobre procedimentos de compra e solicitaram compras; 11 indicaram a necessidade de orientações sobre procedimentos de compra, sobre a justificativa, formulário de compra e cotação de preço, e solicitaram compras; 4 deles solicitaram orientações sobre a justificativa, formulário de compra e cotação de preço; 4 precisaram de orientações sobre a justificativa, formulário de compra e cotação de preço, e sobre solicitaram compras; e 8 apenas solicitaram compras.

A fim de identificar se os solicitantes realizam algum planejamento das demandas futura, questionou-se a adoção de práticas que preveem as necessidades de materiais e/ou serviços. Além disso, coube indagar se os atuais procedimentos dão condição de efetivar esse estudo de previsão. 0 cenário identificado está representado na Figura 6.

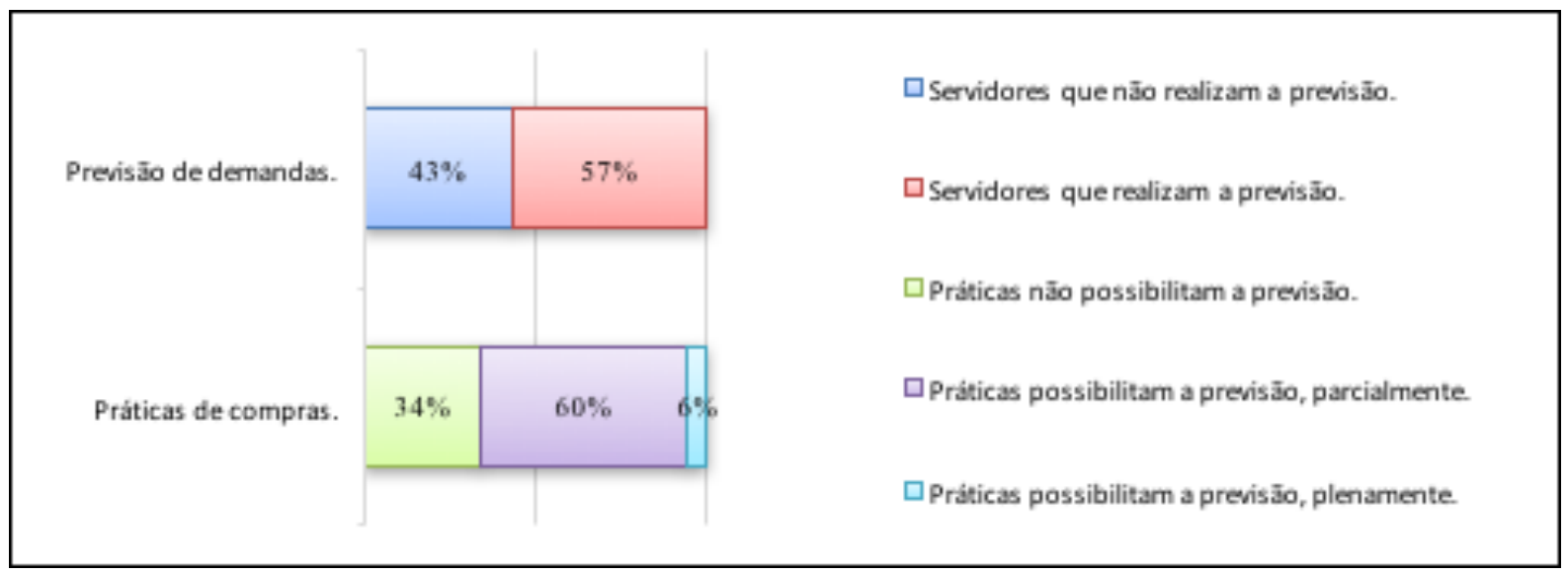

Figura 6: Nível de adoção de práticas para previsão de demanda.

Fonte: Dados da pesquisa (2017). 


\section{ISSN - 2447-178X}

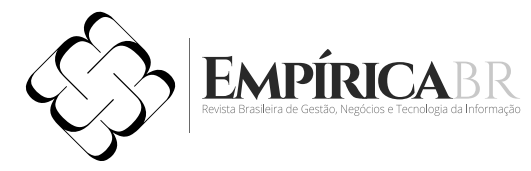

Com base no exposto na Figura 6, identificou-se que parte substancial dos solicitantes afirmaram não realizar a previsão de suas demandas, apesar de a maioria indicar que os procedimentos atuais de compras possibilitam que eles efetuem tal prática. De acordo com Vieira (2016, p. 12) "para que a Administração tenha sucesso, é necessária capacidade de prever, orientar e controlar suas necessidades. A falta de planejamento, leva a Administração a comprar em caráter de urgência, sem observar os princípios constitucionais e básicos da licitação".

Em relação ao atendimento recebido, $46 \%$ dos que já precisaram entrar em contato com o Setor de Compras indicaram que o atendimento foi muito satisfatório, $37 \%$ acharam satisfatório, já $17 \%$ acharam que o atendimento foi pouco satisfatório. Por fim, investigou-se o nível de conhecimento que o solicitante detinha sobre os procedimentos, prazos e documentações necessárias para solicitar uma compra. Para avaliar as respostas, além da totalidade, dividiu-se os respondentes em dois grupos: os que já entraram em contato com o Setor de Compras e os que não, conforme exposto na Figura 7.

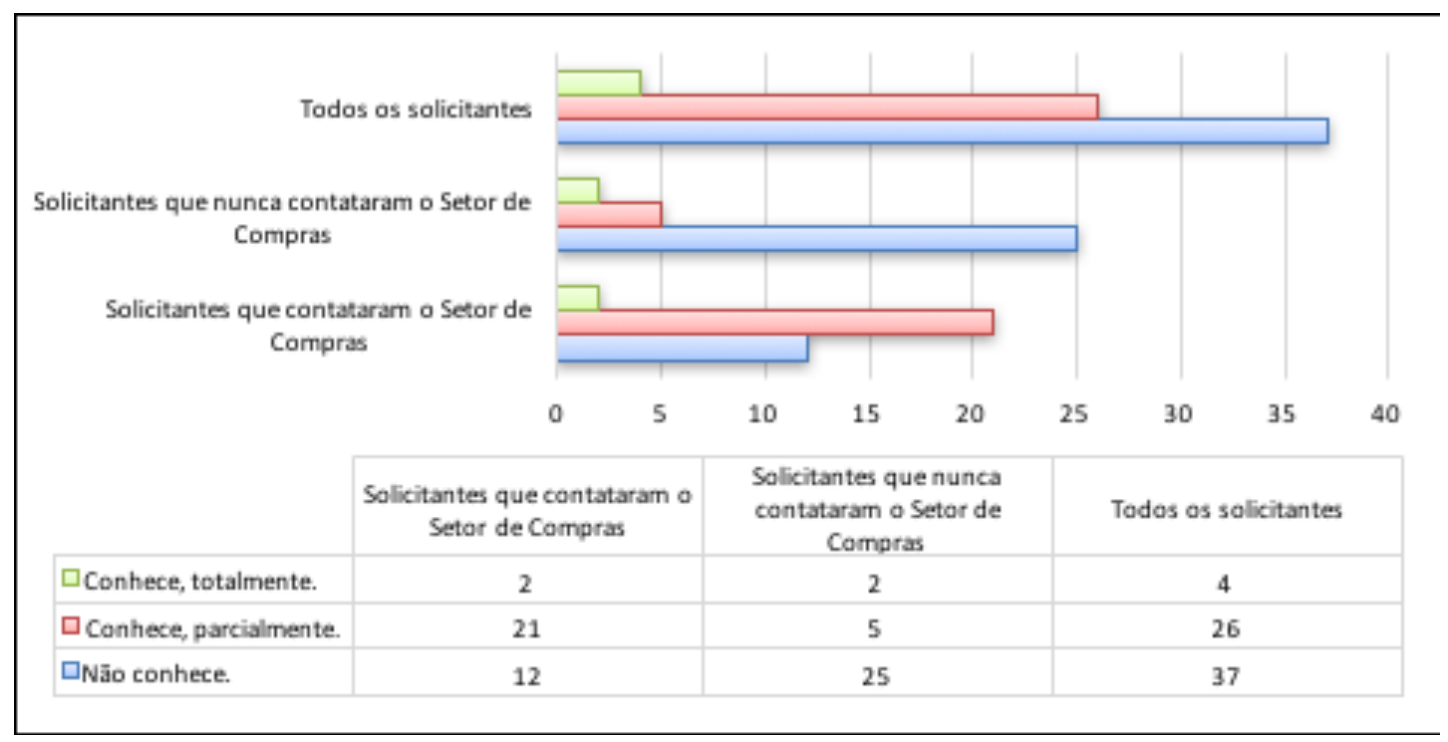

Figura 7: Nível de conhecimento dos solicitantes sobre os procedimentos, prazos e documentos.

Fonte: Dados da pesquisa (2017).

De modo geral, o nível de desconhecimento no que tange aos procedimentos, aos prazos e às documentações necessárias mostra-se elevado, sendo que a grande concentração está no grupo de solicitantes que nunca buscaram o Setor de Compras. No entanto, os dados revelam que, dos servidores que já contataram o setor, muitos passaram pelo processo sem compreender a importância e necessidade de cada fase. Dessa forma, é substancial que os servidores detenham o mínimo de conhecimento sobre esses aspectos e, consequentemente, diminuir substancialmente o risco de insucesso do processo. 


\section{CONCLUSÃO}

Esta pesquisa teve por objetivo avaliar o processo de compras estabelecido pela UFERSA Campus Pau dos Ferros em 2017, objetivando buscar evidências que pudessem aclarar o questionamento inerente a sua eficiência. Para esse fim, foram realizadas entrevistas com os servidores que compõem o Setor de compras e os solicitantes. Àqueles, foram direcionadas indagações sobre aspectos procedimentais das aquisições a fim de compreender e avaliar as práticas adotadas, e a estes buscouse identificar o nível de satisfação com as rotinas de compras da universidade, de conhecimento dos processos internos e a existência de planejamento.

Em relação aos aspectos referentes aos procedimentos das compras, destaca-se que todo o processo que ocorre no âmbito do Campus estudado possui etapas e papéis bem definidos. A ideia da junção das demandas de todos os Campus, através de abertura de Calendário de Compras, apresentase como uma proposta à redução de custos, uma vez que a compra tende a ser maior. No entanto, essa sistemática exige maior nível de planejamento nas projeções das demandas por parte dos solicitantes por se tratar de um processo anual.

No que concerne à capacidade técnica dos gestores, verificou-se a fragilidade dos conhecimentos técnicos dos servidores lotados no Setor de Compras, apresentando-se como uma vulnerabilidade ao processo e a desvalorização da instituição a uma atividade considerável quando se vive uma conjuntura de cortes de recursos. Outro ponto de destaque identificado foi a necessidade de aprimoramento da comunicação entre os servidores gestores e os solicitantes, cujas contribuições podem ser decisivas para que o processo seja mais coordenado e eficiente.

Quanto à avaliação dos solicitantes, observou-se o conflito entre as respostas recebidas pelos gestores em relação aos solicitantes que já buscaram o setor. Os primeiros apontam para a falta de planejamento de longo prazo por parte dos requisitantes, enquanto estes, em sua maioria, afirmam que fazem a previsão das demandas. A inexistência de planejamento e, quando feito, sendo ele ineficaz acarreta na fragilização do processo e na falta de economicidade das compras ao fomentar a aquisição emergencial, sem possibilidade da ampla escolha da oferta mais vantajosa.

Considerando o exposto, percebe-se que, apesar de as práticas e rotinas atuais se colocarem de maneira coerente, observando aspectos no que tange ao planejamento, organização, direção e controle, em diferentes estágios do processo de compras do Campus estudado existem falhas em aspectos importantes inerentes à eficiência. As quais podem gerar consequências relacionadas com a inobservância de dispositivos legais, o aumento dos gastos, as compras desnecessárias, a falta de materiais no momento em que se precisa, o item comprado não atender às necessidades dos requisitantes, dentre outras. Sendo necessário que os gestores implementem políticas para sanar essas lacunas e, consequentemente, propiciar maior precisão no manejo dos recursos públicos direcionados a essa instituição.

Tendo em vista os achados do estudo, recomenda-se a realização de um levantamento capaz de mapear o comportamento de diferentes IFES quanto ao processo de compra. Sugere-se também a criação de um instrumento de coleta apropriado para avaliar os métodos de compras existentes e as 


\section{ISSN - 2447-178X}

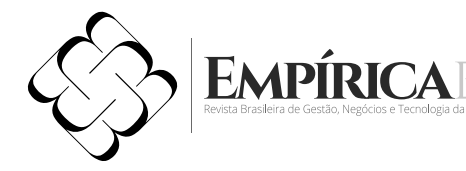

condições da instituição. Além disso, recomenda-se a realização de um estudo mais aprofundado a fim de compreender a percepção dos gestores e solicitantes de compras quanto às metodologias de compras no tocante a essa espécie de serviço público.

\section{REFERÊNCIAS}

1. ALMEIDA JR, S. Gestão de Compra. Rio de Janeiro: Qualitymark, 2012.

2. BATISTA, M. A. C.; MALDONADO, J. M. S. V. O Papel do Comprador no Processo de Compras em Instituições Públicas de Ciência e Tecnologia em Saúde (C\&T/S). Revista de Administração Pública, Rio de Janeiro, v. 42, n. 4, p.681-699, jul/ago 2008. Disponível em: <http://www.scielo.br/pdf/rap/v42n4/ a03v42n4.pdf>. Acesso em: 30 maio 2017.

3. BRASIL. Constituição da República Federativa do Brasil: Texto constitucional promulgado em 5 de outubro de 1988, com as alterações adotadas pelas Emendas Constitucionais n 1/92 a 56/2007 e pelas Emendas Constitucionais de Revisão nº 1 a 6/94. Brasília: Senado Federal, 2008.

4. BRASIL. Lei n. 8.666, de 21 de junho de 1993. Regulamenta o art. 37, inciso XXI, da Constituição Federal, institui normas para licitações e contratos da Administração Pública e dá outras providências. Brasília: Diário Oficial da União, 22 jun. 1993. Disponível em: <http://www.planalto.gov.br/ccivil_03/leis/ L8666cons.htm>. Acesso em: 31 mai. 2017.

5. BRASIL. Lei $n^{\circ} 10.520$, de 17 de julho de 2002. Institui, no âmbito da União, Estados, Distrito Federal e Municípios, nos Termos do Art. 37, Inciso XXI, da Constituição Federal, Modalidade de Licitação Denominada Pregão, Para Aquisição de Bens e Serviços Comuns, e Dá Outras Providências. Brasília, DF, Disponível em: <http://www.planalto.gov.br/ccivil_03/leis/2002/l10520.htm>. Acesso em: 25 set. 2017.

6. BOWERSOX, D. J. et al. Gestão Logística da Cadeia de Suprimentos. 4. ed. Porto Alegre: AMGH, 2014.

7. CASSÃO, F. B. Previsão da Demanda, uma Visão Logística: Um estudo de caso na Secretaria de Assistência Social da Prefeitura Municipal de Santana de Parnaíba. 2014. 73 f. Monografia (Especialização) - Curso de Gestão Pública, Universidade Tecnológica Federal do Paraná, Pato Branco, 2014.

8. CHIAVENATO, I. Recursos Humanos. 5. ed. São Paulo: Atlas, 1998.

9. CUNHA, M. A.; RUIZ, I. A. O Princípio da Eficiência na Administração Pública: propostas para a otimização da cobrança judicial da dívida ativa. In: PEIXE, B. C. S. et al (Org.). Gestão de Políticas Públicas no Paraná: coletânea de estudos. Curitiba: Editora Progressiva, 2008.

10. DALF, R. L. Teoria e Projetos das Organizações. 6. ed. Rio de Janeiro: LTC, 1999.

11. ENAP. Fundação Escola Nacional de Administração Pública (Org.). Logística de Suprimentos: Lei nº 8.666/93, pregão e registro de preços. Brasília: ENAP, 2015.

12. FELICIANO, I. S. Pregão Eletrônico e a Garantia da Qualidade no Processo das Compras Públicas na 


\section{ISSN - 2447-178X}

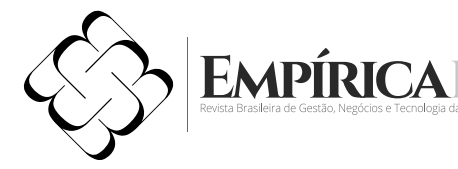

Universidade Federal do Recôncavo da Bahia. 2016. 72 f. TCC (Graduação) - Curso de Tecnologia em Gestão Pública, Centro de Artes, Humanidades e Letras, Universidade Federal do Recôncavo da Bahia, Cachoeira, 2016.

13. GIL, A. C. Métodos e Técnicas e Pesquisa Social. 5. ed. São Paulo: Atlas, 1999.

14. JUTTNER, U. Supply Chain Risk Management: understanding the business requirements from a practitioner perspective. The Internacional Journal of Logistics Management. Vol.16 No. 1, 2005.

15. NOVAES, A. G. Logística e Gerenciamento da Cadeia de Distribuição. Rio de Janeiro: Editora Campus, 2001.

16. MEIRELLES, H. L. Direito Administrativo Brasileiro. São Paulo: Malheiros, 2002.

17. MELO, A. S. Gestão de Compras Públicas: Um estudo de caso na UNIPAMPA - Campus Dom Pedro. 2012. 97 f. Monografia (Especialização) - Curso de Gestão Pública, Universidade Federal do Rio Grande do Sul, Porto Alegre, 2012.

18. OLIVEIRA, M. C. Eficiência do Calendário de Compras para os Processos de Licitação: estudo de caso da Universidade de Brasília. 2015. 134 f. Dissertação (Mestrado) - Curso de Mestrado Profissional em Economia, Departamento de Economia, Universidade de Brasília, Brasília, 2015.

19. PORTAL DA UFERSA. UFERSA em Pau dos Ferros e sua História. 2014. Disponível em: <https:// paudosferros.ufersa.edu.br/ufersa-em-pau-dos-ferros-e-sua-historia/>. Acesso em: 12 ago. 2017. RAMPAZZO, L. Metodologia Científica. São Paulo: Edições Loyola, 2005.

20. RAMPAZZO, L. Metodologia Científica: para alunos dos cursos de graduação e pós-graduação. $3^{\mathrm{a}}$ ed. São Paulo: Loyola, 2005.

21. ROSA, R. A. Gestão Logística. Florianópolis: Departamento de Ciências da Administração/ UFSC; [Brasília]: Capes: UAB, 2012.

22. SANTOS, G. E. O. Cálculo Amostral: calculadora on-line. Disponível em: <http://www. calculoamostral.vai.la>. Acesso em: 02 set. 2017.

23. TRIDAPALLI, J. P.; FERNANDES, E.; MACHADO, W. V. Gestão da Cadeia de Suprimento do Setor Público: uma alternativa para controle de gastos correntes no Brasil. Revista de Administração Pública - RAP, Rio de Janeiro, v. 2, n. 45, p.401-433, mar. 2011.

24. UFERSA. Estatuto da UFERSA. Mossoró: UFERSA, 2016.

25. VIANA, J. J. Administração de Materiais: um enfoque prático. 1. ed. São Paulo: Atlas, 2000. 172p. 26. VIEIRA, A. P. Compras na Administração Pública. Escola Nacional de Administração Pública - ENAP, 2016.

27. VIEIRA, V. (São Paulo). Estadão. Universidades Federais Devem Ter Corte de Até $45 \%$ nos Investimentos. 2016. Disponível em: <http://educacao.estadao.com.br/noticias/geral,federais-devemter-corte-de-ate-45-nos-investimentos,10000068526>. Acesso em: 13 maio 2017. 